\title{
Determination of SCCmec types in methicillin resistant staphylococci isolated from cows and farm workers"
}

\author{
Emel İNEGÖL ${ }^{1}$, Süheyla TÜRKYILMAZ ${ }^{2}$ \\ Adnan Menderes University, ${ }^{1}$ Health Sciences Institute; ${ }^{2}$ Faculty of Veterinary Medicine Department of Microbiology, Aydin- \\ TURKEY.
}

Summary: This study was conducted to determine staphylococcal cassette chromosome mec (SCCmec) types of methicillin resistant staphylococci (MRS) isolated from cattle and farm workers. A total of 145 subclinic mastitic bovine milk and 91 nasal swab samples (56 from cows and 35 from farm workers) were studied for presence of MRS. Methicillin resistance was detected by cefoxitin disc diffusion test. Bacterial identification and methicillin resistance was confirmed by $16 \mathrm{~S}$ rRNA sequencing and mecA PCR, respectively. SCCmec types of these isolates were determined by multiplex PCR targeting for mec and $c c r$ genes, associated IS element and plasmids. Among 236 total samples, 181 staphylococci, 59 of which were found as methicillin resistant were isolated. Fifty nine methicillin resistant isolates originated from 37 (62.7\%) were bovine and 22 (37.3\%) were human. Ten Staphylococcus species [S. haemolyticus (18), S. epidermidis (17), S. aureus (12), S. xylosus (4), S. cohnii (3), S. equorum (1), S. sciuri (1), S. succinus (1), S. pseudointermedius (1) and S. saprophyticus (1)] among 59 MRS were identified by $16 \mathrm{~S}$ rRNA sequence analysis. SCCmec types of 2, 38, 18, and 1 MRS isolates were II, III, IV, and V, respectively. A total of 40 isolates including type II and III were hospital acquired whereas 19 isolates including type IV and V were community acquired. Almost all S. haemolyticus and $S$. aureus isolates carried hospital acquired type SCCmec. The similarity of SCCmec types between human and cattle isolates suggest evidence of transmission from animals to humans, or vice versa. Further studies are needed to establish clonal relationship of MRS isolated from bovine and farm workers with advanced molecular techniques.

Key words: Staphylococcus, methicillin, SCCmec, cattle, human.

\section{Sığırlardan ve sektör çalışanlarından izole edilen metisilin dirençli stafilokoklarda SCCmec tiplerinin belirlenmesi}

Özet: $\mathrm{Bu}$ çalışma sığır ve çiftlik çalışanlarından izole edilen metisilin dirençli stafilokokların (MRS) stafilokokal kaset kromozom mec (SCCmec) tiplerini belirlemek amaciyla gerçekleştirildi. Toplam 145 subklinik mastitisli inek sütü ve 91 burun sivap örneği (56 inekten ve 35 çiftlik çalışanından) MRS varlığı yönünden incelendi. Metisilin direnci sefoksitin disk difüzyon yöntemi ile belirlendi. Bakteriyel identifikasyon ve metisilin direnci sırasıyla 16S rRNA sekansı ve mecA PCR ile doğrulandı. Bu izolatların SCCmec tipleri mec ve $c c r$, IS elementi ve plazmidler için multipleks PCR ile incelendi. Bu 236 örnekten 181 stafilokok izole edilirken bunların 59'u metisilin dirençli olarak belirlendi. Elli dokuz izolatın 37 (\%62.7)'si sığır ve 22 (\%37.3)'si insan orjinliydi. 16S rRNA sekans analizi ile incelenen 59 MRS içinde 10 tür [S. haemolyticus (18), S. epidermidis (17), S. aureus (12), S. xylosus (4), S. cohnii (3), S. equorum (1), S. sciuri (1), S. succinus (1), S. pseudointermedius (1), S. saprophyticus (1)] identifiye edildi. SCCmec tip II, III, IV ve V sırasıyla 2, 38, 18 ve 1 MRS izolatında belirlendi. SCCmec Tip II ve III’ü taşıyan 40 izolat hastane kökenli, SCCmec Tip IV ve V'i içeren 19 izolat toplum kökenli olarak tespit edildi. Hemen tüm S. haemolyticus ve S. aureus izolatlarının hastane kökenli SCCmec tiplerini taşıdığı belirlendi. Sığır ve insan stafilokok izolatlarının taşıdı̆̆ı SCCmec tipleri arasındaki benzerlik hayvanlardan insanlara ya da tam tersi bir bulaşma olabileceğini düşündürmektedir. Sığır ve çiftlik çalışanlarından izole edilen MRS'lar arasındaki klonal ilişkinin belirlenebilmesi için ileri moleküler teknikler kullanılarak gerçekleştirilecek olan çalışmaların yapılmasına ihtiyaç duyulmaktadır.

Anahtar sözcükler: Staphylococcus, metisilin, SCCmec, sığır, insan.

\section{Introduction}

Methicillin, a semisynthetic penicillin that is poorly hydrolyzed by penicillinase, was first used clinically in 1960. Only one year later, Staphylococcus aureus isolates that showed resistance to methicillin were reported (8). Since then, methicillin resistance in staphylococci has appeared in countries worldwide in humans and continues to be one of the most common hospital-acquired pathogens $(18,19,20)$.

It has been shown that methicillin susceptible $S$. aureus (MSSA) can become methicillin resistant $S$. aureus (MRSA) by the acquisition of a staphylococcal

\footnotetext{
This manuscript is prepared from the first name author's master thesis (Project Number: VTF-10026).
} 
cassette chromosome mec ( $\mathrm{SCCmec)}$ element carrying the mecA gene, which is responsible for methicillin resistance by the production of an altered penicillin binding protein (PBP2a) (6). PBP2a is an enzyme involved in cell wall peptidoglycan synthesis. Unlike PBPs of $S$. aureus, PBP2a does not bind to $\beta$-lactam antibiotics with high affinity $(5,19)$.

$\mathrm{SCC} m e c$ elements, unique genomic islands that are found in staphylococcal species, have two essential components, the $c c r$ gene complex and the mec gene complex $(5,16)$. The $c c r$ gene complex is composed of the $c c r$ genes and several of which have unknown functions. The mec gene complex is composed of mecA. Eight different SCCmec elements have been classified under MRSA according to the combination of the mec gene complex class and the $c c r$ gene complex type (5). The SCCmec types I, II, and III are found predominantely in hospital acquired methicillin resistant staphylococci (HA MRS) isolates. The SCCmec types II and III are responsible for the multiple non $\beta$ lactam antimicrobial resistance. The SCCmec type IV and V are typically found in community acquired methicillin resistant staphylococci (CA MRS) strains and lack other multidrug resistance genes (25).

Molecular typing techniques have been used with increasing frequency in studies on epidemiology of methicillin resistant staphylococci (MRS), and also for a better understanding of the evolutionary relationships among MRSA clones (17). The structure of SCCmec can be determined with a number of PCR based methods, such as mecA specific multiplex PCR by Oliveira et al. (17), where different loci on SCCmec type I and IV are detected. The SCCmec typing may provide evidence for the independent deviation of HA MRSA and CA MRSA clones. This data is epidemiologically important for infection control (17).

Staphylococci play a role as nasocomial pathogens in human medicine, as bovine mastitis pathogens in veterinary medicine $(5,18)$. Coagulase negative staphylococci (CoNS) have been recognized as bacteria of minor clinical importance; however, they may now be considered one of the factors that determines the generation of new MRS isolates $(5,7)$. Nowadays, MRS nasal carriage has become a serious problem in farm animals $(5,9)$ as well as in humans $(18)$. There is limited study in farm animals about the molecular epidemiology of MRSA $(23,27,29)$. Also, as far as we know, there is no data on SCCmec typing on methicillin resistant CoNS (MRCoNS) isolates of animal sources in Turkey. The aim of this study was to detect SCCmec types of MRS isolated from cattle and farm workers by PCR.

\section{Materials and Methods}

Material: A total of 145 subclinical mastitic milk obtained from 129 dairy cattle in 15 farms and 91 nasal swab samples (56 from cows and 35 from farm workers) were studied for the presence of MRS.

Sampling: Milk samples were taken as described previously (1). Nasal samples were taken for sampling from the medial septum area of both nostrils by gently rubbing mucosa approximately for $5 \mathrm{~s}$ with a cottontipped swab moistened with sterile water. Nasal swabs were transported to the laboratory in the day of sampling in Amies transport medium in cold chain.

Isolation and phenotypic characterization of staphylococci: The swabs were immediately suspended in $5 \mathrm{ml}$ Tryptone Soya Broth (TSB, Oxoid) containing $7.5 \%$ sodium chloride and incubated for $48 \mathrm{~h} 37^{\circ} \mathrm{C}$ for selective enrichment of staphylococci. Enrichment cultures and milk samples were then streaked on to Mannitol Salt Agar (MSA, Oxoid) to isolate of staphylococci. The staphylococcal isolates were identified morphologically and biochemically by standard laboratory procedures. For discrimination of coagulase positive stahylococci (CoPS) from CoNS, the coagulase test was performed (15).

Identification of MRSA isolates: Staphylococci were tested for methicillin resistance using disc diffusion method with cefoxitin discs ( $30 \mu \mathrm{g}$; Oxoid). Zone radius were read after incubation at $37^{\circ} \mathrm{C}$ for $24 \mathrm{~h}$. Isolates with zone diameter less than $19 \mathrm{~mm}$ for $S$. aureus and $24 \mathrm{~mm}$ for CoNS were considered as methicillin resistant (2), and studied further.

DNA extraction: DNA extraction was performed as described previously (23).

16S rRNA gene amplification for sequence analysis: 16S rRNA gene amplification and sequence analysis were performed as described previously (10). Thus, a large, $1600 \mathrm{bp}$ fragment encoding 16S rRNA gene was amplified and subjected to sequence analysis for species discrimination.

PCR: A MRSA specific PCR assay was performed to discriminate the MRSA from other staphylococci and to genotypically determine methicillin resistance. For the detection of 16S 20 and 1390 universal rRNA, primers 5'-AGA GTT TGA TCC TGG CTC AG-3' and 5'-GAC GGG CGG TGT GTA CAA -3'were used as the forward and the reverse primer, respectively $(21,22)$. For the detection of nuc (S. aureus specific) gene, 5'-GCG ATT GAT GGT GAT ACG GTT-3' was used as forward primer and 5'-AGC CAA GCC TTG ACG AAC TAA AGC-3' was used as the reverse primer (12). For the detection of mecA (methicillin resistance) gene 5'-TCCAGATTACAACTTCACCAGG-3' was used as forward primer and 5'-CCACTTCATATCTTGTAACG-3' was used as reverse primer (17). Five microliters of extracted DNA was used as a template in a $45 \mu \mathrm{PCR}$ mixture containing $1 \times$ PCR buffer $(50 \mathrm{~mm} \mathrm{KCl}, 20 \mathrm{mM}$ Tris $\mathrm{HCl}), 4 \mu \mathrm{l}$ of $25 \mathrm{mM} \mathrm{MgCl}, 2 \mu \mathrm{l}$ of $10 \mathrm{mM}$ deoxynucleoside triphosphate (dNTP) mix, $1.2 \mu \mathrm{l}$ of 100 
pmol each 16S rRNA, nuc and mecA primers, and $3.6 \mu \mathrm{l}$ of Taq DNA polymerase (5U). The amplification of DNA was performed as follows: $94^{\circ} \mathrm{C}$ for $10 \mathrm{~min}$ of initial denaturation; 35 cycles of $94^{\circ} \mathrm{C}$ for $1 \mathrm{~min}, 50^{\circ} \mathrm{C}$ for $1 \mathrm{~min}$ and $72^{\circ} \mathrm{C}$ for $1 \mathrm{~min}$; and a final extension at $72^{\circ} \mathrm{C}$ for $10 \mathrm{~min}$. Visualization of PCR products was performed on $1.5 \%$ agarose gel stained with ethidium bromide. Streptococcus spp. (negative control), S. aureus N315 (positive control) were used as control isolates.

SCCmec typing: SCCmec typing of the isolates to Types I-IV and Type $\mathrm{V}$ was performed using the methods described by Oliveira and Lencastre (17) and Zhang et al. (27), respectively. S. aureus N315 strain was used as the positive control.

\section{Results}

Among 236 samples, 181 staphylococci of which 59 were resistant to methicillin. These MRS isolates were obtained from 12 from out of 15 farms. Methicillin resistance was detected in $24.4 \%(22 / 90), 26.8 \%(15 / 56)$ and $62.8 \%(22 / 35)$ of milk, bovine nasal and human nasal isolates, respectively.

Identification of isolates was done by sequencing a 1371 bp size PCR product by using universal 16S rRNA primers. Ten different Staphylococcus species was identified after sequence analysis (Table 1). S. haemolyticus $(30.5 \%)$ and $S$. epidermidis $(28.8 \%)$ were the two most commonly isolated species, followed by $S$. aureus (20.3\%). The distribution of all staphylococci to the samples was given in Fig 1.

All 59 isolates phenotypically identified as MRS were subjected to a multiplex PCR for confirmation of MRSA isolates. Bacterial DNA control was done by $16 \mathrm{~S}$ rRNA primers. Fragments of expected sizes were 1371, 279 and $162 \mathrm{bp}$ for the 16S rRNA, nuc and mecA genes, respectively (Figure 2). All the 59 MRS isolates identified phenotypically were found to possess both $16 \mathrm{~S}$ rRNA and mec genes, while 12 isolates also possessed the nuc gene. Phenotypically methicillin resistant 47 CoNS isolates were found as negative for nuc gene while all MRSA isolates were found to posses these 3 genes.

Four SCCmec type from 59 MRS isolate were determined using multiplex PCR. Of these 59 materials originated from $37(62.7 \%)$ samples were animal and 22 (37.3\%) were human. SCCmec Type II was found in 2, Type III in 38, Type IV in 18. A single bovine $S$. epidermidis isolate was also found to carry a type $\mathrm{V}$ SCCmec element (Figure 3). While 40 isolates including type II and III were defined as HA MRS, 19 isolates including type IV and V were CA MRS. From bovine nasal swabs 6 were found as CA MRS while, 9 were HA MRS. From human nasal swabs 9 were found as CA MRS, while 13 were HA MRS. From 22 bovine milk isolates 4 were found as CA MRS, while 18 were HA MRS. Distribution of SCCmec elements among MRS are presented in Table 1 .
Table 1. Distrubition of SCCmec elements among MRS based on Staphylococcus species

Tablo 1. MRS izolatları arasında SCCmec elemanlarının Staphylococcus türlerine göre dağ 11 เmı

\begin{tabular}{llcccc}
\hline Species & Number (\%) & \multicolumn{4}{c}{ SCCmec Types=Isolate } \\
& & II & III & IV & V \\
\hline S. haemolyticus & $18(30.50)$ & 0 & 16 & 2 & 0 \\
S. epidermidis & $17(28.80)$ & 1 & 7 & 8 & 1 \\
S. aureus & $12(20.30)$ & 1 & 9 & 2 & 0 \\
S. xylosus & $4(6.70)$ & 0 & 3 & 1 & 0 \\
S. cohnii & $3(5.10)$ & 0 & 1 & 2 & 0 \\
S. equorum & $1(1.72)$ & 0 & 1 & 0 & 0 \\
S. sciuri & $1(1.72)$ & 0 & 0 & 1 & 0 \\
S. succinus & $1(1.72)$ & 0 & 0 & 1 & 0 \\
S. pseudointermedius & $1(1.72)$ & 0 & 0 & 1 & 0 \\
S. saprophyticus & $1(1.72)$ & 0 & 1 & 0 & 0 \\
Total & $59(100.0)$ & 2 & 38 & 18 & 1 \\
\hline
\end{tabular}

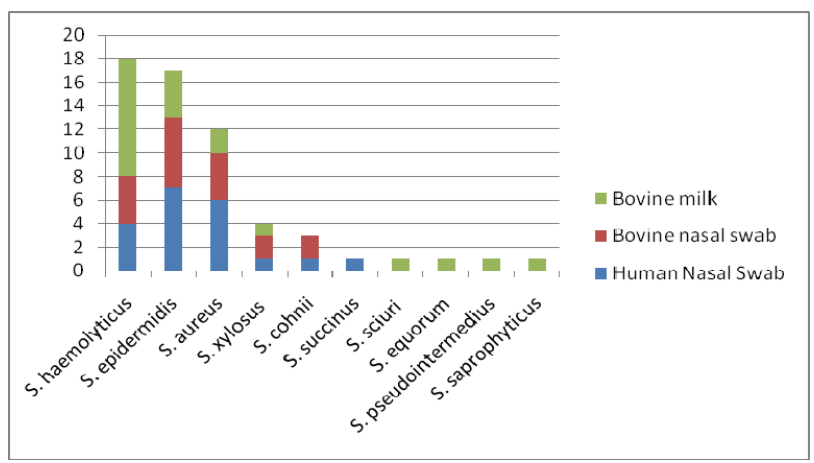

Figure 1. The distribution of staphylococci to the samples Şekil 1. Stafilokok türlerine göre materyallerin dağılımı

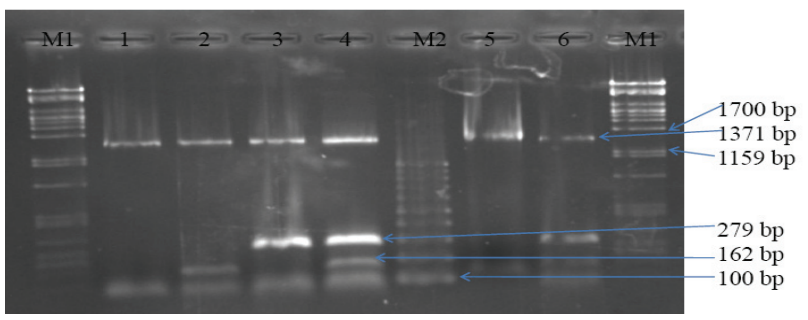

Figure 2. MRSA specific PCR. M1: Marker (Lambda phage DNA restricted with PstI enzyme) 1: Staphylococcus spp. (1371 bp) 2: MRS isolate (1371 bp and $162 \mathrm{bp)} \mathrm{3:} \mathrm{Methicillin}$ sensitive $S$. aureus isolate (1371 bp and $279 \mathrm{bp}$ ) 4: MRSA isolate (1371 bp, $279 \mathrm{bp}$ and $162 \mathrm{bp}$ ) M2: Marker (100 bp DNA ladder) 5: Negative Control (Streptecoccus spp., 1371 bp) 6: Positive Control (S. aureus N315 strain)

Şekil 2. MRSA spesifik PCR. M1: Marker (PstI enzimi ile kesilmiş lambda faj DNA's1) 1: Staphylococcus spp. (1371 bp) 2: Metisilin dirençli stafilokok izolatı (1371 bp ve $162 \mathrm{bp}$ ) 3: Metisilin duyarlı $S$. aureus suşu (1371 bp and 279 bp) 4: MRSA isolate (1371 bp, 279 bp ve 162 bp) M2: Marker (100 bp DNA ladder) 5: Negatif Kontrol (Streptecoccus spp., 1371 bp) 6: Pozitif Kontrol (S. aureus N315 suşu) 


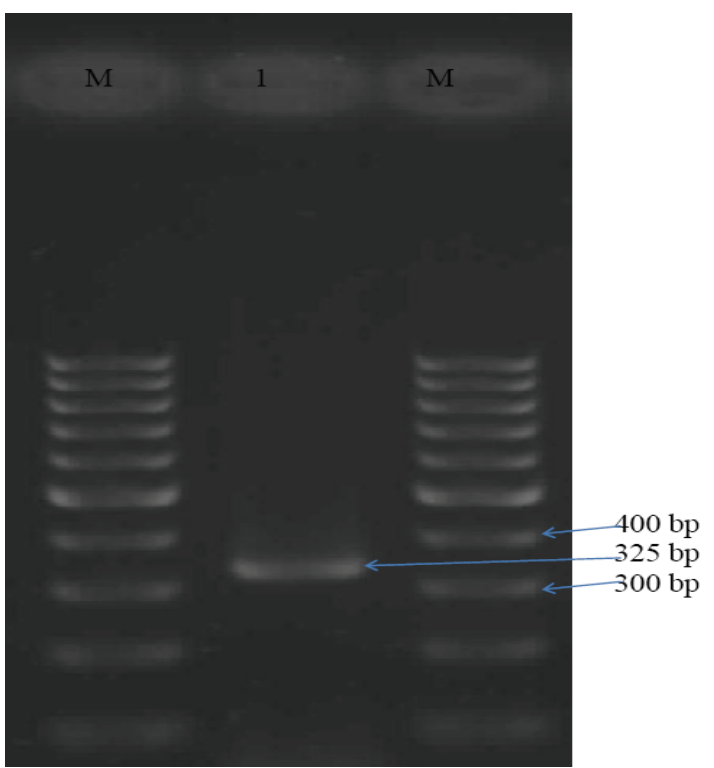

Figure 3. SCCmec type V M: Marker: 100 bp DNA ladder, 1: SCCmec type V (325 bp)

Şekil 3. SCCmec tip V M: Marker: 100 bp DNA ladder, 1: SCCmec tip V (325 bp)

\section{Discussion and Conclusion}

Nowadays methicillin resistance in farm animals has gained particular attention from public health authorities. Infected animals can pass MRS to humans who are in close contact with them. Infections in humans caused by livestock associated MRS have been reported $(9,26)$.

Different isolation rates (5.8-60.0\%) for MRSA were reported in many phenotypic studies held in different years in Turkey $(4,10,11,13,24)$. Performing only phenotypic tests has previously been shown to lead to false positive or false negative results (14). There is only one study in Turkey performed by Türky1lmaz et al. (23) in which phenotypic and genotypic investigation of MRSA isolates isolated from mastitic dairy cattle were investigated and the reported isolation rate was $17.2 \%$. Only one study performed by Kaynarca and Türkyılmaz (10) in which methicillin resistance of CoNS was phenotypically investigated and 10 MRCoNS were isolated.

While the SCCmec typing of MRSA from bovine mastitis have been published $(23,27)$ little information is available on MRCoNS from dairy cattle in the world (3). In the present study, S. epidermidis and S. haemolyticus represented the most frequent species observed among the MRCoNS as were in the study by Febler et al. (3). Similar results were obtained from human patients (20). SCCmec typing identifying mainly type IV elements among $S$. epidermidis isolates from humans (20) and animal origin (29) have been reported.

MRSA colonize most frequently in the anterior nares of the nose and cause serious infections all over the world. In Turkey, MRSA colonization rate was reported very high in some medical centers making MRSA a serious problem (18). In this study, the rate of nasal carriage of MRS among farm workers found to be very high. Nasal carriage rate among cattle was only half of the carriage rate among farm worker which may indicate importance of MRS transfer from human to cattle.

Transmission of MRSA between humans and animals has previously been reported $(9,23)$. Among farm workers, bovine milk and bovine nasal isolates HA MRS (40 isolate) type was higher than CA MRS (19 isolate) type. This situation was especially more important among MRS isolated from bovine. The similarity of SCCmec types between human and cattle isolates suggest evidence of transmission from farm workers to bovine, or vice versa. Further studies are needed to establish clonal relationship of MRS from bovine and farm workers with advanced molecular techniques (Pulsed Field Gel Electrophoresis, Staphylococcal Protein A analysis, Multi Locus Sequence Typing). The result of these studies may shed light on the clonality and transmission of resistance strain between human and animal.

\section{References}

1. Baştan A (2002): Ineklerde Meme Hastalıkları. Hatipoğlu Basım ve Yayım San Tic Ltd Şti, Ankara.

2. Clinical and Laboratory Standards Institute (2008): Performance Standards for Antimicrobial Disk and Dilution Susceptibility Tests for Bacteria Isolated from Animals. 3th. Edition: Approved Standard M31-A3. Wayne, PA, USA.

3. Febler TA, Billerbeck C, Kadlec K, Schwarz S (2010): Identification and characterization of methicillin-resistant coagulase-negative staphylococci from bovine mastitis. $\mathrm{J}$ Antimicrob Chemother, 65, 1576-1582.

4. Hadimli HH, Ateş M, Güler L, Kav K, Öncel T (2001): Mastitisli süt ineklerinden izole edilen stafilokoklartn $\beta$ laktamaz aktiviteleri ve antibiyotiklere duyarlılıkları, Vet Bil Derg, 17, 21-25.

5. International Working Group on the Classification of Staphylococcal Cassette Chromosome Elements (IWGSCC) (2009): Classification of Staphylococcal Cassette Chromosome mec (SCCmec) Elements. Antimicrob Agents Chemother, 53, 4961-4967.

6. Ito T, Katayama Y, Hiramatsu K (1999): Cloning and nucleotide sequence determination of the entire mec DNA of pre-methicillin-resistant Staphylococcus aureus N315. Antimicrob. Agents Chemother, 43, 1449-1458.

7. Ito Y, Ma XX, Takeuchi F, Okuma K, Yuzawa H, Hiramatsu K (2004): Novel type $V$ staphylococcal cassette chromosome mec driven by a novel cassette chromosome recombinase, ccrC. Antimicrob Agents Chemother, 48, 2637-2651.

8. Jevons MP (1961): Celbenin-resistant staphylococci. Br Med J, 124, 124-125.

9. Juhász-Kaszanyitzky É, Jánosi S, Somogyi P, Dán Á, Bloois LG, Duijkeren E, Wagenaar JA (2007): MRSA transmission between cows and humans. Emerg Infect Dis, 13, 630-632. 
10. Kaynarca S, Türkyılmaz S (2010): Methicillin resistance and slime positivity of staphylococci isolated from bovine mastitis. Kafkas Univ Vet Fak Derg, 16, 567-572.

11. Kırkan Ş, Göksoy EÖ, Kaya O (2005): Identification and antimicrobial susceptibility of Staphylococcus aureus and coagulase negative staphylococci from bovine mastitis in the Aydin region of Turkey. Turk J Vet Anim Sci, 29, 791796.

12. Kim CH, Khan M, Morin DE, Hurley WE, Tripathy DN, Jr Kerhli M, Oluoch AO, Kakoma I (2001): Optimization of the PCR for detection of Staphylococcus aureus nuc gene in bovine milk. J Dairy Sci, 84, 74-83.

13. Kireçci E, Çolak A (2002): Kuru dönem başlangıcında subklinik mastitisli ineklerden izole edilen stafilokok suşlarında metisilin direnci. Kafkas Üniv Vet Fak Derg, 8, 98-100.

14. Murakami K, Minamide W, Wada K, Nakamura E, Teraoka H, Watanabe S (1991): Identification of methicillin resistant strains of staphylococci by polymerase chain reaction. J Clin Microbiol, 29, 2240-44.

15. Murray PR (2003): Manuel of Clinical Microbiology, 8th ed. ASM Press, Washington D.C., USA.

16. Oliveira DC, Tomasz A, de Lencastre H (2001): The evolution of pandemic clones of methicillin resistant Staphylococcus aureus: identification of two ancestral genetic backgrounds and the associated mec elements. Microb Drug Resist, 7, 349-361.

17. Oliveira DC, de Lencastre H (2002): Multiplex PCR strategy for rapid identification of structural types and variants of the mec element in methicillin-resistant Staphylococcus aureus. Antimicrobial Chemother, 46, 2155-61.

18. Oztop AY, Pinarbasi H, Kocagoz S, Bakici MZ, Bakir M (2004): Molecular genotyping of methicillin-resistant Staphylococcus aureus strains in a teaching hospital in Turkey. Microb Drug Resist, 10, 154-159.

19. Rohrer S, Bischoff M, Rossi J, Berger-Bachi B (2003): Mechanisms of methicillin resistance. In: Fluit, A.C., Schmitz, F.-J. (Eds.), MRSA. Current Perspectives. Caister Academic Press, Wymondham.

20. Ruppe' E, Barbier F, Mesli Y et al. (2009): Diversity of staphylococcal cassette chromosome mec structures in methicillin-resistant Staphylococcus epidermidis and Staphylococcus haemolyticus strains among outpatients from four countries. Antimicrob Agents Chemother, 53, 442-449.
21. Sghir A, Antonopoulos D, Mackie RI (1998): Design and evaluation of a lactobacillus group-specific ribosomal RNA-targeted hybridization probe and its application to the study of intestinal microecology in pigs. Syst Appl Microbiol, 21, 291-296.

22. Suau A, Bonnet R, Sutren M, Godon JJ, Gibson G, Collins MD, Dore'J (1999): Direct rDNA community analysis reveals a myriad of novel bacterial lineages within the human gut. Appl Environ Microbiol, 65, 4799-4807.

23. Türkyılmaz S, Tekbıyık S, Oryasin E, Bozdogan B (2010): Molecular epidemiology and antimicrobial resistance mechanisms of methicillin-resistant Staphylococcus aureus isolated from bovine milk. Zoonoses Public Health, 57, 197-203.

24. Türütoğlu H, Erçelik S, Öztürk D (2006): Antibiotic resistance of Staphylococcus aureus and coagulase negative staphylococci isolated from bovine mastitis. Bull Vet Inst Pulawy, 50, 41-45.

25. Ünal S (2006): Toplumda kazanılmış metisilin dirençli Staphylococcus aureus. Genetik özellikler. Ankem Derg, 20, 100-1.

26. Van Hoovels L, Vankeerberghen A, Boel A et al. (2006): First case of Staphylococcus pseudintermedius infection in a human. J Clin Microbiol, 44, 4609-4612.

27. Vangerhaeghan W, Cerpentier T, Adriaesen C, Vicca J, Hermans K, Butaye P (2010): Methicillin resistant Staphylococcus aureus (MRSA) ST398 associated with clinical and subclinical mastitis in Belgian cows. Vet Microbiol, doi: 10.1016/j.vet-mic.200912.044

28. Zhang K, McClure JA, Elsayed S (2005): Novel multiplex PCR assay for characterization and concomitant subtyping of staphylococcal cassette choromosome mec types I to V in methicillin resistant Staphylococcus aureus. J Clin Microbiol, 43, 5026-33.

29. Zhang Y, Agidi S, LeJeune JT (2009): Diversity of staphylococcal cassette chromosome in coagulasenegative staphylococci from animal sources. J Appl Microbiol, 107, 1375-1383.

Geliş tarihi: 27.09.2010 / Kabul tarihi: 12.07.2011
Address for Correspondence:
Dr. Süheyla Türkyllmaz
Department of Microbiology,
Faculty of Veterinary Medicine,
Adnan Menderes University, 09010, Işıklı, Aydın, Turkey.
E-mail: sturkyilmaz@adu.edu.tr 